\title{
Bakı şəhərində göstərilən narkoloji xidmətinin xarakteristikası
}

\author{
P.P.Məmmədov ${ }^{1}$ \\ ${ }^{1}$ Respublika Narkoloji Morkaz
}

Açar sözlor: narkoloji xidmət, psixotrop maddalain təsiri, naromaniyanın gizlilik dəracasi

Tədqiqatın aktuallığı. Hal-hazırda Azərbaycan Respublikasının «Narkotik vasitələrin, psixotrop maddələrin və onların prekursorlarının dövriyyəsi haqqinda» $[5,6]$ və «Narkoloji xidmət və nəzarət haqqında» [3, 4] qanunları əhaliyə narkoloji yardımın göstərilməsi qaydasını müəyyən edir. Azrbaycan Respublikasının «Narkoloji xidmət və nəzarət haqqinda» qanununun 5.6 maddəsinə əsasən, narkotik asıllıqdan müalicənin anonimliyinə dair zəmanət xəstələrin dövlət narkoloji mərkəzlərinə müraciətinin sayının artmasına və narkomaniyanın gizlilik dərəcəsi səviyyəsinin azalmasına səbəb olmuşdur. Halhazıradək, Respublika höküməti tərəfindən bu cür yardım qaydasını və onun əlçatan olmasını müəyyən edən müvafiq qərarlar qəbul edilmişdir. Lakin, anonimlik şəraitində epidemioloji tədqiqatların keçirilməsi və remissiya göstəricilərinin analizi ilə bəzi problemlər yaranır. Həmçinin narkotiklərdən asılılıq üzrə müalicə kursu almış xəstələrə ənənəvi dinamik dispanser nəzarətinin həyata keçirilməsi və onların residiv əleyhinə tədbirlərlə əhatə olunması da çətinləşmişdir.

\section{Tədqiqatın nəticələri və müzakirəsi.} Azərbaycan Respublikası Səhiyyə Nazirliyi psixoaktiv maddələrdən asıllıqdan əziyyət çəkən şəxslərə yardımın göstərilməsinə istiqamətləndirilmiş müəyyən addımlar atır. Belə ki, Azərbaycan Respublikasının SN 1 sentyabr 2000-ci il tarixli 119 saylı əmri ilə, narkoloji xidmət sərbəst xidmət olaraq təsdiq edilmiş və psixiatrik xidmətdən ayrılmışdır, tibbi ixtisaslar strukturuna isə "həkim-narkoloq" ixtisası daxil edilmişdir. Azerbaycan Respublikası SN 14 iyul 2011-ci il tarixli 63 saylı əmri ilə, Respublika narkoloji dispanseri Respublika Narkoloji Mərkəz olaraq yenidən təşkil edilmişdir. Lakin, halhazıradək, mövcud olan narkoloji xidmət narkotiklərdən istifadə vəziyyəti ilə tam adekvat deyil və bu xidmət işinin göstəriciləri problem miqyasına uyğun deyil, narkomaniyanın yayılma dərəcəsi göstəricilərindən, narkotiklərdən istifadə modellərin və növlərinin genişlənməsindən geridə qalır. Eyni zamanda qeyd etmək lazımdır ki, psixoaktiv maddələrdən asıllığa, ələlxüsus narkomaniyaya və narkotik (psixoakriv) vasitələrin qanunsuz dövriyyəsinə qarşı aparılan mübarizə daim dövlətin diqqət mərkəzində olmaqla, insanların sağlamlığına və mənəviyyatına sarsıdıcı zərbə vuran bu kimi halların aradan qaldırılması üçün kompleks tədbirlər həyata keçirilmiş, hüquqi və inzibati islahatlar aparılmış, təbliğat işləri genişləndirilmiş, profilaktik tədbirlərin səmərəliliyi artırılmışdır. Ölkə ərazisində narkomanlığa və narkotik vasitələrin qanunsuz dövriyyəsinə qarşı aparılan mübarizə sahəsində hüquqi məsələləri tənzimləyən qanunvericilik bazasının yaradılması və bu bazanın dəyişən şəraitə və tələblərə uyğunlaşdırılması Azərbaycan dövlətinin və müvafiq qurumların əsas fəaliyyət istiqamətlərindən biri olmuşdur. Belə ki, bu məsələ ilk dəfə "Narkomanlığa və narkotik vasitələrin qanunsuz dövriyyəsinə qarşı tədbirlər haqqında" Azərbaycan Respublikasının Prezidenti Ümummilli Lider Heydər Oliyevin 1996-c1 il 26 avqust tarixli 485 nömrəli Fərmanında öz əksini tapmaqla, insanların sağlamlığının, rifahının və mənəvi-əxlaqi dəyərlərinin qorunması və narkomanlığa, narkotiklərin qanunsuz dövriyyəsinə qarş1 mübarizə ümumdövlət vəzifəsi kimi müəyyən edilmiş, həmçinin narkotiklərin qanunsuz 
dövriyyəsi və narkomanlıqla mübarizə sahəsində dövlət siyasətinin strateji istiqamətləri dəqiq göstərilmişdir. $\mathrm{Bu}$ strateji kurs Azərbaycan Respublikasının Prezidenti cənab İlham Oliyev tərəfindən uğurla davam etdirilərək, problemə dəyişən şəraitə və tələblərə uyğun yanaşılması dövlətin əsas prioritetlərindən birinə çevrilmiş, bu sahədə qətiyyətli mübarizənin təmin edilməsi məqsədilə sayca beşinci "Narkotik vasitələrin, psixotrop maddələrin və onların prekursorlarının qanunsuz dövriyyəsinə və narkomanlığa qarşı mübarizəyə dair 2019-2024-cü illər üçün Dövlət Proqramı” 22 iyul 2019-cu il № 1334 Sərəncamı ilə təsdiq edilmişdir [1]. Dövlət Proqramının məqsədi ölkədə narkotik vasitələrin, psixotrop maddələrin və onların prekursorlarının qanunsuz dövriyyəsinə və narkomanlığa qarşı mübarizənin gücləndirilməsi, antinarkotik təbliğat, narkotiklərin qanunsuz alınması, narkomanlığa düçar olmuş şəxslərin müalicə edilməklə, sağlam həyata qaytarılması, müalicə-bərpa sahəsindəki fəaliyyətin müasir dövrün tələblərinə uyğunlaşdırılması, bu sahədə qanunvericiliyin təkmilləşdirilməsi, cəza tədbirlərinin səmərəliliyinin öyrənilməsi üçün elmi və praktik araşdırmaların aparılması, beynəlxalq əməkdaşlığın inkişaf etdirilməsi və digər geniş miqyasl1 məsələlərdən ibarətdir. $\mathrm{Bu}$ dovlət proqramında olkəmizdə narkotiklərin qanunsuz dovriyyəsi və narkomanlıqla mübarizə sahəsində dövlət tərəfindən narkomaniyanın birincili profilaktikasının strateji istiqamətləri muəyyən olunmuşdur.

Bunula yanaşı, Azərbaycan Respublikası Səhiyyə Nazirliyi tərəfindən narkomanlığa düçar olmuş şəxslərin mualicə və reabilitasiyası istiqamətində Respublikada Narkoloji Mərkəzini müasir texniki vasitələrlə, narkoloji xəstələrin aşkara cıxarılması üçün lazım olan ekspress testlərlə, müvafiq dərman preparatları ilə tam şəkildə təmin edir. Hal-hazırda, Bakı ş. narkoloji xidmətinin sərəncamında RNM-də 200 çarpayı mövcuddur. RNM-nin büdcə maliyyələşdirilməsi haqqinda məlumatlar cədvəl 1-də təqdim edilmişdir.

\section{Codval 1}

RNM-nin maliyyələşdirilməsi (manatla)

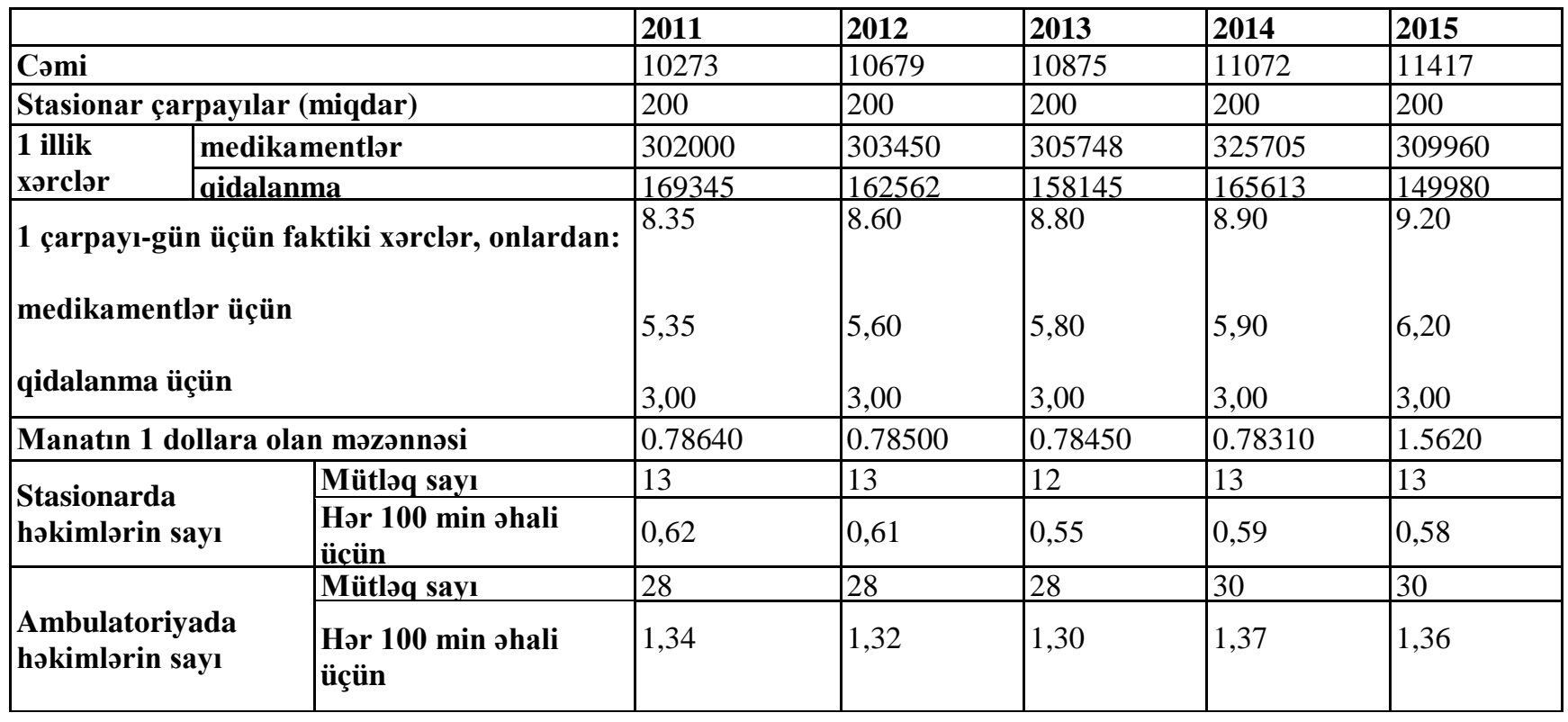


Cədvəldəki məlumatlardan görünür ki, 5 il ərzində, Bakı şəhərində narkoloji xidmətin maliyyələşdirilməsində artım qeyd olunur, bu maliyyələşdirməyə o cümlədən medikamentlərə və qida məhsullarına çəkilən xərclər də daxildir. Belə ki, 2011-ci ildə sutkada bir xəstə üçün medikamentlərə çəkilən xərclər 5.35 manat, qida xərcləri 3.00 manat təşkil edirdisə, 2015-ci ildə bu göstəriciliər 6.20 və 3.0 manat təşkil etmişdir. Lakin ABŞ dolları kursunun kəskin şəkildə artması ilə əlaqədar olaraq, son ildə dollarla ifadə edildiyi zaman medikament və qida xərcləri, 2011-ci illə müqayisədə, 2015-ci ildə 10.6 ABŞ dollarından 5.9 ABŞ dollarına qədər azalmışdır. Respublika Narkoloji Mərkəzində heroindən asılı xəstənin stasionar müalicəsinin orta müddəti (əsasən, detoksikasiya), 14-21 gün təşkil edir. Beləliklə, 2011-ci ildə bir nəfər bu cür xəstə üçün klinikada olduğu bütün müddət ərzində medikament və qida xərcləri təxmini 148.4 - 222.6 ABŞ dolları məbləğində nəzərdə tutulurdusa, 2015-ci ildə bu göstərici 82.6 - 123.9 ABŞ dolları təşkil etmişdir. Qiymətləndirmələrimizə görə, heroin narkomanının bir kurs müalicəsi üçün tam medikament dəstinin dəyəri Bakı ş. qiymətləri çərçivəsində 250 ABŞ dolları təşkil edir. Bakı şəhərində stasionar narkoloji yardımı 13 həkimnarkoloq göstərir. Onlar RNM-nin müxtəlif şöbələrində çalışırlar. Bu göstərici hər $100 \mathrm{~min}$ əhali üçün hesablandıqda, 0.58 təşkil edir. $\mathrm{Bu}$ göstərici digər MDB ölkələrindəki, xüsusilə də Rusiya Federasiyasındakı (hər 100 min əhali üçün 0.39) [9] və Qazaxıstan Respublikasındakı (hər 100 min əhali üçün 0.4) [8] həkim-narkoloqlarla təmin edilmə göstəricilərindən çoxdur.

Bak1 şəhərində narkotik istifadəçilərinin rəsmi statistikasına əsaslanaraq, müalicəyə olan tələbatı tam şəkildə qiymətləndirmək mümkün deyil, bu isə rəsmi qaydada qeydiyyata alınmış narkomaniya xəstələrinin say1 ilə qiymətləndirmə sayı arasındakı böyük fərqlə əsaslandırılır. Eyni zamanda, Respublika Narkoloji Mərkəzinə stasionar yardım üçün müraciət sayı göstəriciləri narkotik asılılıqdan əziyyət çəkən şəxslərin sayının artmasını (demək olar ki, 4 dəfə) göstərir (2011-ci ildə - 250 xəstə, 2015-ci ildə - 1050 xəstə). Lakin, Bak1 şəhərində Narkoloji xidmətin məcburi dispanser qeydiyyatı institutunu özündə saxladığına görə, narkotiklərdən asılı olanlar yardım üçün qorxaraq müraciət etmirlər.

Bak1 şəhərində narkotik asılılığının ambulator müalicəsi iki ixtisaslaşdırılmış narkoloji müəssisədə həyata keçirilir: Respublika Narkoloji mərkəzində və şəhər narkoloji dispanserində. $\mathrm{Bu}$ narkoloji yardım növü 30 həkim-narkoloq tərəfindən göstərilir, bu isə, hər 100 min əhali üçün hesablandıqda, 1.36 təşkil edir, bu isə digər MDB ölkələrindəki həkim-narkoloqlarla təmin edilmə göstəricilərindən çoxdur. Dövlət tərəfindən anonim narkoloji yardımla əlaqədar zəmanət təmin edilir. Hal-hazırda, reabilitasiya proqramları, yüksək dərəcədə asılı olanlarla fəaliyyət əlçatmazdır, onları təşkil etmək və inkişaf etdirmək lazımdır. Bunu nəzərə alaraq, Azərbaycan Respublikası Nazirlər Kabineti 2014-cü il 13.09 tarixdə 276 nömrəli qərarı ilə «Narkomanlığa düçar olmuş şəxslərin müalicəsi, reabilitasiyası və resosializasiyası üzrə Proqram»ını təsdiq etmiş [2] və Respublika Narkoloji Mərkəzinin nəzdində 20 çarpaylıq reabilitasiya şöbəsinin təşkili nəzərdə tutulmuşdur.

Məlum olduğu kimi, narkotiklərdən asılı olanların müalicəsinin effektivliyinin göstəricilərindən biri remissiyanın davam etmə müddətidir - bu, müalicə kursundan sonra, müalicə almış xəstənin təkrar narkotiklərdən istifadə etməkdən çəkindiyi müddətdir. 2011 - 2015 illərdə xəstələrin remissiyası analizini həyata keçirmiş RNM-nin məlumatlarına əsasən, remissiyanın 6 aydan 1 ilədək (2011-ci ildə - xəstələrin 19.6\%, 2015-ci ildə - xəstələrin 21.7\%) və 1 ildən 2 ilədək (2011-ci ildə - xəstələrin 8.4\%, 2015-ci ildə xəstələrin 11.6\%) artması qeyd edilmişdir.

Yuxarıda qeyd edilmiş amillər və asan keçid, 
narkotiklərin, xüsusilə də heroinin nisbətən aşağ qiyməti Bakı şəhərində narkomaniyanın olduqca sürətli şəkildə yayılmasına səbəb olmuşdur. Qeyd etmək lazımdır ki, ənənəvi opiatlardan fərqli olaraq, heroindən asılılığın formalaşması, epizodik istifadə mərhələsi həyata keçmədən, çox sürətli baş verir.

Narkoloji yardımın təşkilati formaları müəyyən dərəcədə xəstəliyin proqnozuna, formalaşmasına və yayılmasına təsir göstərir. Bakı şəhərində və ümumilikdə Respublika üzrə narkoloji xidmətin humanizasiya və yardımın əlçatan olması, xidmətlərin keyfiyyətinin artırılması, xidmət çeşidlərinin genişləndirilməsi istiqamətində yenidən formalaşdırılması, habelə dövlət müalicə-profilaktika müəssisələrinin cəlbediciliyinin təmin edilməsi, yardımın məxfiliyinə və anonimliyinə dair zəmanətin verilməsi zəruridir. Yeni normativ-hüquqi sənədlərin hazırlanması yaxın gələcəkdə bu istiqamətdə xidmətin yenidən formalaşdırılmasını təmin edəcək, mürəkkəb sosial problem kimi narkomaniya ilə mübarizədə müəyyən rol oynayacaq:

$\mathrm{Bu}$ istiqamətdə strateji sənəd Azərbaycan Respublikasının Prezidenti cənab İlham Oliyevin 22 iyul 2019-cu il № 1334 Sərəncamı ilə təsdiq edilmiş sayca beşinci "Narkotik vasitələrin, psixotrop maddələrin və onların prekursorlarının qanunsuz dövriyyəsinə və narkomanlığa qarş1 mübarizəyə dair 2019-2024-ci illər üçün Dövlət Proqramı"dir [1]. Bundan əvvəlki və hazırki Dovlət Proqramlarının icrası ilə bağlı Təhsil Nazirliyi tərəfindən qanun pozuntularına meylli olan yetkinlik yaşına catmayanların yaşayış yerləri, işlədiyi və təhsil aldığı inzibati ərazilər üzrə yerli icra hakimiyyəti və bələdiyyələr, polis orqanları, əmək kollektivləri və müvafiq komissiyalar arasında əlaqələrin genişləndirilməsi,onların narkomaniya ilə bağlı profilaktik tədbirlərlə əhatə olunması məqsədilə təhsil muəssisələrinin rəhbərlərinə müvafiq göstərişlər verilmiş, yerlərdə, xüsusən də polis idarələrinin yetkinlik yaşına catmayanlarla iş üzrə müvəkkilləri və tibb işciləri ilə mütəmadi olaraq pedaqoji kollektivlərin göruşləri təşkil edilmişdir. Gənclər və İdman Nazirliyi tərəfindən respublikanın bir sıra şəhər və rayonlarında yeniyetmə və gənclərin asudə vaxtlarının səmərəli təşkil edilməsi məqsədilə "Sağlam həyat tərzi və reproduktiv sağlamlıq üzrə təlim vəsaitinin tanıdılması və yayılması layihəsi" həyata kecirilmiş, qeyri-hökümət təşkilatları tərəfindən icra edilən layihələr cərcivəsində lazımi cap məhsulları hazırlanaraq, gənclər, idman idarələri və gənclər təşkilatları arasında paylanmışdır. Mudafiə Nazirliyi tərəfindən xüsusi təyinatl təhsil müəssisələrinin tədris proqramına sağlam həyat tərzi və narkomanlığın ziyanı ilə bağlı mövzular daxil edilmiş, şəxsi heyətlə aparılan tərbiyə işinin təşkili zamanı və keçirilən hüquq hazırlığı saatlarında narkomaniya və onun fəsadları barədə məlumat verilmiş, sənədli filmlər nümayiş olunmuşdur. Səfərbərlik və Hərbi Xidmətə Çağırış uzrə Dovlət Xidməti tərəfindən birincili hərbi qeydiyyata alınan gənclər və müddətli həqiqi hərbi xidmətə cağırılan vətəndaşlar arasında narkotik aludəçiliyi əleyhinə təbliğat işi aparılmış, çağırışaqədər yaş həddində olan vətəndaşlar barəsində aidiyyəti üzrə narkoloji dispanserlərə sorğular göndərilmiş, narkomanlıq xəstəliyi aşkar ediləcəyi təqdirdə müalicənin təmin edilməsi istiqamətində tibb müəssisələri ilə qarşılıqlı tədbirlərin görülməsi planlaşdırılmışdır. Ailə, Qadın və Uşaq Problemləri üzrə Dövlət Komitəsi tərəfindən narkomanlıqla mübarizə sahəsində maarifləndirmə işləri aparılmış, Әdilyyə Nazirliyinin Penitensiar Xidməti ilə birlikdə yetkinlik yaşına çatmayanlar üçün Tərbiyə Müəssisəsində görüşlər olmuş, müəssisədə olan uşaqların cəmiyyətə inteqrasiyası, onların asudə vaxtlarının səmərəli təşkili, dünya görüşlərinin və intellektlərinin artırılması, fiziki inkşafının və sağlam həyat tərzinin formalaşdırılması, valideyinləri ilə görüşlərin kecirilməsi, digər 
ehtiyaclarının öyrənilməsi istiqamətində tədbirlər görülmüşdür. "Sağlam ailə sağlam gələcəyin təminatıdır" adlı layihə çərçivəsində şəhər və rayon qeydiyyat şöbələrinə nikaha daxil olmaq üçün ərizə ilə muraciət edən gənclərə sağlam həyat tərzi, nikaha daxil olan şəxslərin tibbi müayinəsinin əhəmiyyəti kimi məsələlər barədə izahat işləri aparılmış, "Reproduktiv sağlamlıq, nikahdan əvvəl tibbi muayinə”, "Sağlam həyat tərzi seçin”, "QİCS sağalmaz xəstəlikdir", "QİCS analizini ver! Riski sıfira endir!" adlı bukletlər hazırlanaraq paylanılmışdır. Milli Televiziya və Radio Şurası tərəfindən narkotik vasitələrin, psixotrop maddələrin və onların prekursorlarının qanunsuz dövriyyəsi və narkomanlığa qarşı mübarizə tədbirlərinin kütləvi informasiya vasitələrində geniş işıqlandırılması, həmçinin bu sahədə maarifləndirmə işlərinin gücləndirilməsi məqsədilə cap materiallarının və sosial roliklərin hazırlanması kimi vəzifələrin yerinə yetirilməsi üçün teleradio yayımçılarına müvafiq tövsiyələr verilmişdir. Azərbaycan Milli Elmlər Akademiyasında tədqiqat institutlarının əməkdaşlarından ibarət yaradılmış işçi qrup tərəfindən narkotik vasitələrin, psixotrop maddələrin və onların prekursorlarının qanunsuz dövriyyəsi və narkomanlığın mənfi nəticələrinin aradan qaldırılması məqsədilə maarifləndirici işlər aparılmış, Akademiyanın Fiziologiya İnstitutunda müvafiq tədqiqatlar aparılmış, ilk dəfə respublika üzrə narkotik vasitələrin yayılma arealını əks etdirən xəritə hazırlanaraq, xidməti istifadə üçün aidiyyəti qurumlara göndərilmişdir. Azərbaycan Respublikasının Prezidenti yanında QeyriHökümət Təşkilatlarına Dövlət Dəstəyi Şurası bir il ərzində narkomanlığa qarşı mübarizə istiqaməti üzrə 23 layihəyə 187.500,0 AZN vəsait ayırmış, layihələr əsasən Bakı, Şirvan, Hacıqabul, Salyan, Masallı, Lənkəran, Astara, Saatlı, Sabirabad, Bərdə, Yevlax, Qəbələ, Şəki, İsmayı1ll, Göycay, Ağdaş, Tərtər, Ağcabədi, Quba, Qusar, Xacmaz, Oğuz, Gəncə, Tovuz və s. rayon və şəhərlərdə 75 təlim, 28 seminar, 30 digər tədbirlər kecirilmişdir.
Azərbaycan Respublikası Baş Nazirinin müavini, Narkomanlığa və Narkotik Vasitələrin Qanunsuz Dövriyyəsinə Qarş1 Mübarizə üzrə Dovlət Komissiyasının sədri cənab Oli Həsənovun tapşırığına əsasən narkomanlığın cəmiyyətə və insanların sağlamlığına ziyanı barədə təbliğat aparılması məqsədilə və "26 iyun - BMT-nin Narkotiklərlə Mübarizə Günü” ilə əlaqədar Dövlət Komissiyasının işçi qrupu və digər aidiyyəti qurumlarla birgə bir sıra tədbirlər kecirilmișdir. Eyni zamanda, narkomanlığın zərəri barədə əhalinin məlumatlandırılması məqsədilə Narkomanlığa və Narkotik Vasitələrin Qanunsuz Dövriyyəsinə Qarş1 Mübarizə üzrə Dövlət Komissiyasının işçi qrupu tərəfindən hazırlanmış "Narkomaniyaya birlikdə yox deyək" adlı xususi loqo Nəqliyyatı İntellektual İdarəetmə Mərkəzinin 14 yerləşmə lövhəsində işıqlandırılmışdır. Bunlardan əlavə, "26 iyun - BMT-nin Narkotiklərlə Mübarizə Günü” ilə əlaqədar respublikanın bütün şəhər və rayonlarında "Narkomaniya gələcəyin bəlasıdır", "Narkotiklrədən ozümüzü qoruyaq", "Gənclər narkotiksiz həyat namimə" və sair şuarlar altında silsilə tədbirlər keçirilmiş, tədbirlərdə yeniyetmələr, gənclər, müəllimlər və valideyinlər iştirak etmiş, narkotikin törətdiyi fəsadlar barədə müzakirələr aparılmışdır. Cəmiyyətin muxtəlif yaş təbəqələrindən olan insanlarla narkomaniya ilə mübarizə aparılmasının yolları, narkotik maddələrin zərərli olduğu bilindiyi halda istifadəsinin niyə sürətlə artdı̆̆ının səbəbləri haqqında müzakirələr aparılmış, iştirakçıların 75 faizi yeniyetmə və gənclər, 25 faizi isə orta yaşı insanlar olmuşdur.

Səhiyyə Nazirliyi və Təhsil Nazirliyinin birgə "Narkotiklərə YOX deyək!” şuarı altında keçirdiyi kompaniyada, Ailə, Qadın və Uşaq Problemləri üzrə Dövlət Komitəsinin mütəxəssisləri ilə, Narkomanlığa və Narkotik Vasitələrin Qanunsuz Dövriyyəsinə Qarşı Mübarizə üzrə Dövlət Komissiyasının işçi 
qrupunun mütəxəssisləri ilə keçirilən birgə təlimlərdə, İcra hakimiyyəti və polis şöbəsinin təşkilatçılığı ilə keçirilən tədbirlərdə Respublika Narkoloji Mərkəzinin mütəxəssisləri iştirak etmişdir. İIV-infeksiyasının inyeksion narkotik istifadəçiləri (İNI) arasında yayılmasının qarşısının alınması istiqamotində Respublika Narkolojı Mərkəzi ilə 2014-cü ildən başlayaraq vaxtaşırı işgüzar görüşlər keçirilir, aşkarlanan İNİ-lərin İIVinfeksiyasına müayinəsi və göstəriş üzrə İIV-li xəstələrin narkomanlığa müayinələri üzrə məlumat mübadiləsi və nəticələri müzakirə olunur. Gənclər və risk qrupu nümayəndələrinin müayinələrə cəlb olunmasında birgə tədbirlər həyata keçirilir. Təşkilati tədbirləri stiqamətində RQMM tərəfindən RespublikaNarkoloji Mərkəzi, Bak1, Sumqayıt, Lənkəran, Mingəçevir şəhər narkoloji dispanserləri və bir sıra MRX-1n narkoloji kabinetləri nəzdində İIV-ə könüllü müayinə və məsləhətləşmə məntəqələri təşkil edilmişdir (KMM). Səhiyyə Nazirliyinin internet saytında (www.health.gov.az), Respublika Narkoloji Mərkəzinin internet saytında (www.rnm.az), www.saglamliq.isim.az, "İnter.az" və "Media.az" internet kanallarında Narkotik vasitələrin, psixotrop maddələrin və onların prekursorlarının qanunsuz dövriyyəsinə və narkomanlığa qarşı mübarizə sahəsində aparılan işlər və bu bəlaya düçar olmamağın yolları barədə mütəmadi olaraq təbliğat aparırlar. Narkomaniyanın zərərli tərəflərini əks etdirən profilaktik tədbirlərin keçirilməsi üçün lazımı texniki vasitələrlə təmin olunmuş, kinofilm, prezentasiya nümayiş etdirilir və həmin tədbirləri icra edənlərin peşəkarlığının artırılması üçün müvafiq təlimlər keçirilib.

Narkomaniyanın profilaktikası və onun terapiyası əhalinin sosial-mədəni xüsusiyyətlərinin nəzərə alınması ilə təşkil olunmalıdır. Profilaktik və terapevtik tədbirlər differensiasiyalı şəkildə, regionun sosial-demoqrafik, iqtisadi, etno-mədəni xüsusiyyətlərinin nəzərə alınması ilə həyata keçirilməlidir.
Yekun. Oldə edilmiş nəticələrə əsasən, Bakı şəhərində narkomaniya xəstələrinə narkoloji yardımın təkmilləşdirilməsinin əsas istiqamətləri hazırlanmalıdır. İlk növbədə, respublika psixi sağlamlıq mühafizəsi proqramı hazırlanmalıdır ki, bu proqramda narkomaniyanın ohalinin etnomədəni xüsusiyyətlərinin nəzərə alınması ilə profilaktikası məsələlərinə xüsusi diqqət ayırmaq lazımdir. $\mathrm{Bu}$ proqramın yaradılması və həyata keçirilməsinə sadəcə həkim-narkoloqlar deyil, həmçinin tibbi psixoloqlar, müxtəlif sosial sektorda işləyən işçilər, təhsil nümayəndələri mütəxəssislər, dini xadimlər və ictimai təşkilatlar da cəlb edilməlidir. Ohalinin hər bir subpopulyasiyasında risk qruplarına xüsusi diqqət ayrılmalıdır, çünki burada xəstəliyə tutulma dərəcəsi yüksəkdir.

İlkin profilaktika proqramları differensiasiyalı olmalıdırlar və xalqun mədəniyyət anlayışını və dinini, milli tərbiyə və ailə münasibətləri ənənələrini, cinsini, yaşını, təhsil səviyyəsini və peşə mənsubiyyətini nəzərə almalıdır. Bu zaman, mütəxəssislər və aktivistlər narkomaniyanın artmasina və yayılmasına mənfi təsir göstərən, xüsusilə də, etnomədəni xüsusiyyətlərə malik olan (bizim əhalimiz üçün uşaqların avtoritar stildə tərbiyə edilməsi, boş inancların yüksək dərəcədə yayılması, sosial nəzarətin aşağı səviyyədə olması, icma səviyyəsində antinarkotik davamlılıq amillərinin assimilyasiyası, öz somatik sağlamlığının vəziyyətinə qarşı düşüncəli münasibətin olmaması, intihar ehtimallarına qarşı səbirli münasibət və s.) amillərlə tanış olmasına diqqəot verməlidirlər.

Narkomaniyanın ilkin profilaktikası zamanı, sosial nəzarətin rolunun artırılması üzrə tədbirlər görmək, yüksək dərəcədə asılı olanların, sosialəhəmiyyətli şəxslərin və din xadimlərinin kompleks terapevtik tədbirlərdə, tibbi-sosial reabilitasiya proqramlarında və residiv əleyhinə tam dəstək tədbirlərinin, icma səviyyəsində sosial müşahidə proqramlarının həyata keçirilməsində aktiv şəkildə iştirak etməsini təmin etmək lazımdır. 
Ohali arasında effektiv ilkin profilaktik tədbirlərin təşkil edilməsi və həyata keçirilməsi zamanı, bu layihələrin reallaşdırılmasında sosial-əhəmiyyətli şəxslərin, icma aktivistlərinin, dini xadimlərin iştirak etmələri xüsusi əhəmiyyətə malikdir. $\mathrm{Bu}$ zaman, mütəxəssislər və aktivistlər narkomaniyanın artmasına və yayılmasına mənfi təsir göstərən, xüsusilə də, etnomədəni xüsusiyyətlərə malik olan amillərlə tanış olmasına diqqət verməlidirlər.

İkincili profilaktikanın həyata keçirilməsi zamanı, həkim-narkoloqlar bilməlidirlər ki, narkoloji yardımın təşkilati formaları müəyyən dərəcədə əhalinin sosial-demoqrafik və etnomədəni xüsusiyyətlərindən asılı olaraq həyata keçirilməlidir. Narkomaniya xəstələrinin, habelə bu patologiyanın yayılması üzrə yüksək risk qruplarının erkən diaqnostikası və aktiv şəkildə aşkar edilməsi üzrə işin gücləndirilməsi lazımdır. Residivlərin mövcud olmasına dair xəbərdarlıq işinin aktivləşdirilməsi və reabilitasiya proqramlarının, "zərərin azaldılması" proqramlarının, xüsusilə də xoşagəlməz xəstəlik proqnozu olan xəstələr arasında reallaşdırılması tələb olunur. $\mathrm{Bu}$ məqsədlərlə, respublikada tibbisosial reabilitasiya və resosializasiya xidmətlərinin yaradılması lazımdır. Həkim-narkoloqların və tibbi psixoloqların hazırlanması respublikada yaşayan əhalinin etno-mədəni xüsusiyyətlərinə, psixologiyasına və psixiki sağlamlığına dair biliklərə malik olmaqla həyata keçirilməlidir.

Həyata keçirilmiş tədqiqatlar təsdiq edirlər ki, narkoloji yardımın təşkilatı formaları müəyyən dərəcədə regionun kliniki, sosial-demoqrafik və etnomədəni xüsusiyyətlərindən asılı olaraq həyata keçirilməlidir ki, bunlar, digərləri ilə yanaşı, xəstəliyin proqnozuna, formalaşmasına və yayılmasına təsir göstərirlər.

Yuxarıda qeyd olunanlara yekun olaraq, qeyd etmok lazımdır ki, differensiasiyalı yanaşmaların Bakı ş. və Azərbaycan Respublikasının narkoloji təcrübəsində tətbiq edilməsi narkomaniya xəstələrinin psixoprofilaktik, müalicə-diaqnostik və reabilitasiya yardımının effektivliyinin artırılması və əhalinin psixiki sağlamlığının möhkəmləndirilməsinə yatırım edilməsi üçün imkanlar yaradacaq. Biz N.A. Oliyevin və Z.N. Oliyevin [7] Azərbaycan Respublikası dövlət orqanlarının psixoaktiv maddələrin, xüsusilə də narkotiklərin istifadəsi səviyyəsinin azaldılması üzrə fəaliyyətinin daha çox aktivləşdirilməsi zərurəti haqqında fikirləri ilə razıyıq.

Maliyyə Mənbəyi: Məqalənin hazırlanmasında heç bir kənar maliyyə mənbəyindən istifadə edilməyib.

Maraqların toqquşması: Qeyd edilməyib.

\section{ӘDӘBIYYYAT:}

1. "Narkotik vasitələrin, psixotrop maddələrin və onların prekursorlarının qanunsuz dövriyyəsinə və narkomanlığa qarşı mübarizəyə dair 20192024-cü illər üçün Dövlət Proqramı" Azərbaycan Respublikasının Prezidenti cənab İlham Oliyevin 2013-cu il 22 iyul 2019-cu il № 1334 Sərəncamı ilə təsdiq edilmişdir.

2.«Narkomanlığa düçar olmuş şəxslərin müalicəsi, reabilitasiyası və resosializasiyası üzrə Proqram» Azərbaycan Respublikas1 Nazirlər Kabineti 2014-cü il 13.09 tarixdə 276 nömrəli qərarı.

3.«Narkoloji xidmət və nəzarət haqqında» Azərbaycan Respublikasının Qənunu, Bakı, 17 sentyabr 2001-ci il.

4."Narkoloji xidmət və nəzarət haqqında" Azərbaycan Respublikasının Qanununda dəyişikliklər edilməsi barədə Azərbaycan Respublikasının Qanunu, Bakı şəhəri, 6 oktyabr 2015-ci il.

5."Narkotik vasitələrin, psixotrop maddələrin və onların prekursorlarının dövriyyəsi haqqında" Azərbaycan Respublikasının Qanunu, Bak1 şəhəri, 28 iyun 2005-ci il.

6."Narkotik vasitələrin, psixotrop maddələrin və onların prekursorlarının dövriyyəsi haqqında" Azərbaycan Respublikasının Qanununda dəyișikliklər edilməsi barədə Azərbaycan 
Respublikasının Qanunu, Bakı şəhəri, 6 oktyabr 2015-ci il.

7.Алиев Н.А., Алиев 3.Н. Современное состояние наркологической ситуации в Азербайджане по данным государственной статистики // Наркология, №11, 2015, с 1520.

8.«Мониторинг наркологической ситуации для Республики Казахстан». Аналитический отчет, Павлодар, 2015.

9.Корнилов Н.Г. Доклад антинаркотической комиссии «Об основных проблемах обеспечения населения Иркутской области наркологической помощью». Иркутск, 2011. 